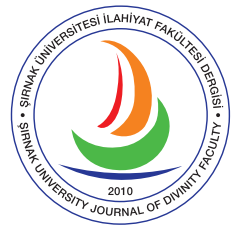

e-ISSN 2667-6575

\title{
İslam Fıkhına Göre İhramlı Halde Evlilik
}

Marriage in Ihram According to the Islamic Figh

\section{Fatih Çinar}

Dr., Osmaniye Korkut Ata Üniversitesi, İlahiyat Fakültesi, İslam Hukuku Ana Bilim Dalı

PhD, Osmaniye Korkut Ata University, Faculty of Divinity

Department of Islamic Law

Osmaniye, Turkey

fatih11982@hotmail.com

https://orcid.org/0000-0002-5901-3135

\section{Makale Bilgisi / Article Information}

Makale Türü / Article Types: Araştırma Makalesi / Research Article

Geliş Tarihi / Received: 23 Ocak / January 2020

Kabul Tarihi / Accepted: 23 Şubat / February 2020

Yayın Tarihi / Published: 15 Haziran / June 2020

Cilt / Volume: 11 Sayı / Issue: 24 Sayfa / Pages: 186-205

Atıf / Cite as: Çinar, Fatih. “İslam F1khına Göre İhramlı Halde Evlilik [Marriage in Ihram according to the Islamic Fiqh]". Şırnak Üniversitesi Ilahiyat Fakültesi Dergisi - Şırnak University Journal of Divinity Faculty 11/24 (June 2020), 186-205. https://doi.org/10.35415/sirnakifd.679327

Etik Beyanı / Ethics Declaration: Bu makalede bilimsel araştırma ve yayın etiği ilkelerine riayet edilmiştir. Makale etik izin gerektirmeyen bir çalışma olup en az iki hakem tarafından incelenmiş ve intihal içermediği teyit edilmiştir./ In this article, the principles of scientific research and publication ethics are respected. The article is a study that does not require ethical permission. It has been reviewed by at least two referees and was confirmed that it did not contain plagiarism.

Copyright (C) Published by Şırnak Üniversitesi, İlahiyat Fakültesi / Şırnak, Türkiye (Şırnak University, Faculty of Divinity, Şırnak, 73000 Turkey). 


\title{
Öz
}

Bu makalede ihramlı olmanın evliliğe engel olup olmadığı hususuna açıklık getirilmeye çalışılmıştır. İslam fıkhına göre sahih bir evlilik akdinin inşası için belirli şartların bulunması gerekli görülmüştür. $\mathrm{O}$ şartlardan biri evlenecek kadın ve erkeğin aralarında evlenmeye mani bir haramlık bulunmuyor olmasıdır. Esasında muharremât olarak ifade edilen nikâh engelleri kavramı evlenilmesi yasak olan kadınları nitelemektedir. Fakat bu kadınlar açısından erkekler de aynı kapsamda değerlendirilir. Evlilik engelleri sürekli ve geçici olmak üzere iki kısma ayrılır. İhramlı olma vasfı geçici bir durum olduğundan ihramlı bir kadınla evlilik meselesi geçici evlilik engelleri bağlamında ele alınmaktadır. İhramlı olmanın evlenmeye mâni olup olmadığı hususunda temelde iki görüş bulunmaktadır. Her iki görüş sahibi fakihler bazı deliller zikretmiştir. Âlimlerin pek çoğu ihramlı olmanın evlilik akdi yapmaya engel olduğu kanaatini benimsemiştir. İhramın evliliğe engel olmadı̆̆ını ifade eden başta Hanefîler olmak üzere bir kısım fakih buna karşı çıkmıştır. Hanefî fakihler yasağın ihramlı halde nikâhlanmak olmadığını, aksine bu sırada cinsel ilişki kurmak olduğunu belirtmiştir. İhramlı halde cinsel ilişki kurulamayacağı hususundaki görüş birliği aslında Hanefîlerin kanaatlerini desteklemektedir.

Anahtar Kelimeler: F1kıh, Evlilik, Akit, Muharremât, İhram.

\begin{abstract}
In this article, it has been tried to clarify whether being ignorant is an obstacle to marriage. According to Islamic fiqh, certain conditions were required for the construction of a valid marriage contract. One of those conditions is that there is no obstacle to marriage between men and women who will marry. The concept of marriage barriers, which is basically referred to as muharramât, characterizes women who are forbidden to marry. But according to these women, men are evaluated within the same scope. Marriage barriers are divided into two parts, permanent and temporary. Since it is a temporary situation, the issue of marriage to a woman with a woman is handled within the context of temporary marriage barriers. There are basically two opinions as to whether or not being offended prevents marriage. The scholars with both views cited some evidence. Many scholars have agreed that being irrelevant prevents marriage contract in ihram. Many scholars, especially the Hanafi jurists, who stated that the ihram is not an obstacle to marriage, opposed this. Hanafi jurists stated that the ban was not to be married in ihram, on the contrary to have sexual intercourse during this time. The consensus that no sexual intercourse can be established in the form of support, in fact, supports the opinions of Hanafis.
\end{abstract}

Keywords: Fiqh, Marriage, Contract, Muharramât, Ihram. 


\section{Extended Abstract}

Marriage is a humanitarian necessity. Meeting this necessity plays an important role in ensuring social peace and happiness. Because marriage is the reason for the existence of children who are considered fruit of marriage. In this respect, marriage and family which is natural result of the marriage are the smallest unit of society. The prerequisite for the formation of the family is to make a legitimate marriage contract. Relations without marriage are not legitimate, and they also constitute an obstacle to formation of family. For this reason, every step that allows marriage is considered valuable. It is extremely important that Islam promotes marriage. As a matter of fact, Islam has made many arrangements in this direction. On the other hand, Islam has eliminated the difficulties that prevent marriage. Naturally, Islam has followed a facilitating way. However, it is an undeniable fact that some situations constitute an obstacle to marriage.

For this reason, in this article, it has been tried to clarify whether being in ihram is an obstacle to marriage. Therefore, obstacles to marriage has been mentioned in summary. According to Islamic fiqh, certain conditions were required for the construction of a valid marriage contract. One of those conditions is that there must not be forbiddance to marriage between men and women who will marry. The concept of marriage obstacles, which is basically referred to as muharramât, characterizes women who are forbidden to marry. But according to these women, men are evaluated within the same scope. This issue has been handled in detail in fiqh books. Considering these works, many issues constitute obstacles to marriage. Fundamentally, marriage obstacles are divided into two parts, permanent and temporary. Some situations, such as being siblings, are examples of permanent marriage barriers. Parties with permanent marriage disabilities were never allowed to marry. Even if marriage occurs, it is not legitimate. The parties must divorce immediately. Situations such as a woman being married to another man constitute an example of temporary marriage disability. In this case, it is not legitimate to get married. If marriage has occurred despite the prohibition, it is imperative that the parties leave immediately. Since it is a temporary situation, the issue of marriage to a woman in ihram is handled within the context of temporary marriage obstacles. However, it should be noted that there is a difference of opinion on this matter. There are basically two opinions as to whether or not being in ihram prevents marriage. The scholars with both views cited some evidence. Among these evidences there are some verses and hadiths. Some 
of these evidences can be listed as follows: According to the narration narrated by Ibn Abbas, the Prophet married to Meymûne at a time when he was in ihram. According to Abu Râfi', the Prophet was not in ihram when he married to Meymûne. According to Hz. Osman, the Prophet forbade to marry in the ihram state. The verse about pilgrimage was also conveyed in this context.

Both parties applied to rational evidence. However, it should be said that the focus of the discussion is the narrations mentioned. On the other hand, the parties also applied to the evidence of comparison. It seems that both groups of scholars have tried to support their views from various perspectives. However, it is necessary to state that some evidence is common to both groups of scholars. In other words, both groups of scholars stated that the same evidence supports their views. Many scholars have agreed that being in ihram prevents to make a marriage contract. These scholars have criticized the views of their opponents. Thus, they tried to override their opinions and evidence. Many scholars, especially the Hanafi jurists, who stated that the ihram is not an obstacle to marriage, opposed this. These scholars have also criticized the views of their opponents. Hanafi jurists stated that the ban was not to be married in ihram, on the contrary to have sexual intercourse during this time. According to this, Hanafi jurists stated that marriage was not forbidden. As a result, the evaluations made by both groups are seen to be consistent in themselves. In this respect, it is thought that there is no contradiction between the evidences. However, it can be said that the evaluations of Hanafi scholars are more convincing. The consensus that no sexual intercourse can be established in the state of ihram, in fact, supports the opinions of Hanafis. Because, while a person is busy with worship, it will be appropriate to stay away from behavior that will harm the pilgrimage and umrah. As it is clear, what really forbidden is not a marriage contract, but to have sexual intercourse. 


\section{GİRIŞ ${ }^{1}$}

Pek çok şer'î nasta evlilik yapmak, tabiatıyla aile kurmak teşvik edilmiştir. Diğer yandan evliliğin belli kurallara tabi olduğu bilinmektedir. Bu çerçevede İslam fıkhına göre evlilik akdinin münakit ve sahih sayılabilmesi için belirli şartların bir araya gelmesi elzemdir. Bu şartlardan birine göre evlenecek kadın ve erkeğin aralarında evlenmeye mani bir haramlık bulunmaması gerekir. Ne var ki ihramlı kadınla evlilik meselesinin bu şartlar kapsamında olup olmadığ 1 ise tartışma konusu olmuştur. ${ }^{2}$

İhramlı kadının evlilik meselesi fürû-i fıkıh eserlerinde tartışılan bir konudur. Ancak bu hususu doğrudan ele alan herhangi bir müstakil çalışma bulunmamaktadır. Bu konuya temas eden "İslâm Aile HukukundaEvlenmeEngelleri II (GeçiciEvlenmeEngelleri)" başlıklı makalede mesele kendisine detaya girilmeden yani yüzeysel denilebilecek bir şekilde yer bulmuştur. Muharremât konulu diğer birkaç makalede ise çalışma konumuza değinilmemiştir. Bu itibarla bizim makalemiz açısından bu çalışmalar herhangi bir engel teşkil etmemektedir.

Anlaşıldığı kadarıyla Hanefî fakihlerin ihramlı halde evliliğe cevaz veren görüşleri işaret edilen çalışmalarda ve İslam Aile Hukuku başlıklı müstakil eserlerde bu konuya yer verilmemesi gibi bir sonuç doğurmuştur. Oysaki aşağıda geleceği üzere aslında konu Hanefî kaynaklarında savunmacı bir üslupla da olsa kifayet edecek düzeyde ele alınmıştır. Aslında meselenin ahvâlü'ş-şahsiyye ismiyle kaleme alınmış kimi Arapça eserlerde ihmal edildiği saptanmıştır ki bu da söz konusu alanda bir boşluk olduğunu göster-

\footnotetext{
1 Bu makale 8-10 Mart 2019 tarihlerinde Adana'da düzenlenen İksad III-Uluslararası Sosyal Bilimler Kongresi'nde sunulan "İslam Fıkhına Göre İhramlı Kadınla Evlilik Meselesi" başlıklı bildirinin makaleye dönüştürülmüş halidir. / This article is a transcript of the paper entitled "The Issue of Marriage to Woman with Ihram According to the Islamic Fiqh" was presented at the Iksad III - International Social Sciences Congress in Adana on 8-10 March 2019.

2 Şamil Dağcl, "İslâmAileHukukundaEvlenmeEngelleriII(GeçiciEvlenmeEngelleri)",Anka ra Üniversitesi İlahiyat Fakültesi Dergisi 41/1 (2000), 186.
} 
mektedir. Binâenaleyh mevzu bahis konunun açıklı̆̆a kavuşturulması adına kaleme alınan bu yazının söz konusu boşluğu doldurma adına katkı sağlayacağı aşikârdır. Bu sebeple genel olarak mezheplerin görüşleri dikkate alınarak problemin vuzuha kavuşturulması için gayret sarf edilecektir. Bu bağlamda gerek klasik gerekse muasır eserler derinlemesine araştırılacaktır. Elde edilen bulgular tasnif ve tahlil edilerek bir kanaate varılmaya çalışılacaktır.

\section{EVLENME ENGELI}

Nikâh akdinin sıhhat kazanması için muharremât olarak nitelenen bir evlenme engelinin bulunmaması şarttır. Kadınları niteleyen muharremât kavramının gereği olarak esasında kadına göre erkek de bu kapsamda değerlendirilir. Evlilik engelleri sürekli ve geçici olmak üzere iki kısma ayrılır. ${ }^{3}$

Sürekli evlenme engeli sayılan haramlık vasfı kadın ve erkekten sakıt olmadığından tarafların birbirileriyle evlilik yapmaları asla mümkün değildir. ${ }^{4}$ Bu durumda nikâh kıyılsa dahi söz konusu akit sıhhat kazanmaz, aksine onun butlanı gerekir. Ancak taraflar arasında cinsel birliktelik cari olmuşsa nikâh şüphesi bulunması hasebiyle kadın ve erkeğe had cezası tatbik edilmez. Bununla birlikte onların bu beraberliği hemen sonlandırmaları şarttır. Eğer kadın ve erkek birlikte yaşamaya devam ederse bu takdirde hâkim onların arasını tefrik etmekle yükümlüdür. ${ }^{5}$

Geçici evlenme engelleri için de aynı durum geçerlidir. Fakat geçici evlenme engellerine rağmen vaki olan nikâh akdi bâtıl değil de fâsid olarak da nitelenir. Akdin fâsid olması bazı fıkhî sonuçlar meydana getirir. İhramlı bulunmak kadın veya erkeğe sürekli bir haramlık vasfı kazandırmadığından ihramlı kadınla evlilik meselesi kimi âlimler tarafından geçici evlilik engelleri çerçevesinde ele alınmaktadır. İhramlı bulunmayı muharremât kapsamında değerlendirmeyen âlimler ise meseleyi muarızlarına cevap verme babında ele almışlardır.

\section{MESELE HAKKINDA FAKİHLERİN GÖRÜŞÜ}

İhramlı halde nikâhlanmak hususunda İslam âlimleri arasında iki görüş mevcuttur. Bu itibarla burada iki alt başlık halinde âlimlerin bu görüşlerine temas edilecektir.

3 Ömer Nasuhi Bilmen, Hukukı İslâmiyye ve Istılahatı Fıkhiyye Kamusu (İstanbul: Bilmen Yayınevi, 1976), 2/8.

${ }^{4}$ Abdulkerim Zeydan, el-Mufassal fì ahkâmil-mer'e vel-beytül-müslim fi'ş-şerîati'l-İslâmiyye (Beyrut: Müessesetü'r-Risâle, 1993), 6/200.

5 Abdulvehhâb Hallâf, Ahkâmu'-ahvâli'ş-şahsiyye fí'ş-şerî‘atil-İslâmiyye (Kuveyt: Dâru'lKalem, 1990), 39, 41. 


\section{1. İhramlı Halde Evliliğe Cevaz Veren Âlimler}

İhramlı olmanın evlilik engeli olmadığını ifade eden pek çok sahabî, tâbiîn ve fakih bulunmaktadır. Bunlar arasında Abdullah b. Mesûd (öl. 32/652-53), Abdullah b. Abbas (öl. 68/687-88), Enes b. Mâlik (öl. 93/71112); ${ }^{6}$ Atâ (öl. 103/721), İkrime (öl. 105/723) ve Kufe ehli bulunmaktadır. ${ }^{7}$ Yine İbrâhim en-Nehaî (öl. 96/714), Kâsım b. Muhammed (öl. 107/725), Ebû Hanîfe (öl. 150/767) ve Süfyân es-Sevrî (öl. 161/778) de bu görüşü benimsemiştir. ${ }^{8}$ İsimleri zikredilen sahabî, tâbiîn ve diğer fakihler dikkate alındığında cumhura bu konuda muhalefet eden Hanefî âlimlerin yalnız olmadığı anlaşılmaktadır.

\section{2. İhramlı Halde Evliliğe Cevaz Vermeyen Âlimler}

İkinci görüşs sahiplerine göre ihramlı halde evlenmek yasaklanmış olduğundan her iki tarafın da nikâh yapması için ihramdan çıkmış olmaları şarttır. Bu sebeple onlara göre ihrama girmek geçici evlilik engeli oluşturur. Bu görüşü savunanlar arasında da pek çok sahabî ve tâbiîn bulunmaktadır. Hatta Kâdî İyâz (öl. 544/1149) ashaptan olanların önde gelenler olduğunu ifade ederek bu görüşün daha sağlam olduğunu ihsas ettirir. ${ }^{9}$ Hz. Ömer (öl. 23/644), Hz. Ali (öl. 40/661), İbn Ömer ve Zeyd b. Sâbit (öl. 45/665) bu sahabîlerdendir. Saîd b. el-Müseyyeb (öl. 94/713), Sâlim b. Abdullah (öl. 106/725) ve Süleyman b. Yesâr (öl. 107/725) gibi tâbiîn fakihi de bu grupta yer alır. Fakihlerden Evzâî (öl. 157/774), Leys b. Sa'd(öl. 175/791), İmam Mâlik (öl. 179/795), İmam Şâfiî (öl. 204/820) ve İmam Ahmed b. Hanbel (öl. 241/855) de bu görüşü benimsemiştir. ${ }^{10}$ İbn Hazm (öl. 456/1064) da bu görüşü tercihe lâyık bulmuştur. ${ }^{11}$

İkinci görüş sahiplerinin cumhur olduğu ifade edilmiştir. ${ }^{12}$ Kanaatimizce dört mezhep açısından doğru olan bu ifadenin genel müctehidler açısından yerinde kullanıldığını söylemek güçtür. Çünkü azınlık oldukları ileri sürülen birinci görüşs sahipleri içindeki sahabî, tâbiîn ve fakihle-

6 Ebû Cafer Ahmed b. Muhammed et-Tahâvî, Şerhu me'ân i'-âsâr (Beyrut: Âlemü'l-Kütüb, 1994), 2/273.

7 Ebu'l-Fazl Ahmed İbn Hacer el-Askalânî, Fethu'-bârî bi-şerhi Sahîhi'l-Buhârî (Beyrut: Dâru'lMa'rife, 1960), 4/52.

8 Ebû Cafer Ahmed b. Muhammed et-Tahâvî, Muhtasaru İhtilâfi'-'ulemâ (Beyrut: Dâru'lBeşairi'l-İslâmiyye, 1995), 2/114.

9 Ebu'l-Fazl Kâdî İyâz, İkmâlu'-Mu'lim bi-fevâidi Müslim (Mansûre: Dâru'1-Vefâ, 1998), 4/552.

${ }^{10}$ Ebu'l-Ferec İbn Kudâme, eş-Şerhu'-kebîr 'alâ metni'-Mukni', (Beyrut: Dâru'l-Kitâbi'l-Arabî, 1983), 3/312.

${ }^{11}$ Ebû Muhammed Ali İbn Hazm, el-Muhallâ bi'-âsâr (Beyrut: Dâru'l-Kütübi'l-ilmiyye, 2003), $5 / 211$.

${ }^{12}$ Vehbe ez-Zuhaylî, el-Fikhu'-İ́slâmî ve edilletuh (Dımaşk: Dâru'l-Fikr, 1985), 7/79. 
rin ilmî seviye ve şöhretleri izahtan varestedir. Bu beyanımıza karşılık bu yazıda tarafların kısa ve belirgin bir biçimde ifade edilebilmesi için onlar Hanefîler ve bu konudaki onların muarızları olan Mâlikî, Şâfiî, Hanbelî ve diğer fakihler cumhur olarak nitelendirilecektir.

\section{FAKİHLERINN DELILLERI}

Hanefî fakihler ve cumhurun görüşlerini ispatlama adına bazı şer'î naslarla istidlal ettikleri görülmektedir. Esasında bunların bir kısmı her iki tarafça delil olarak getirildiği için onların bir başlık altında aktarılması uygun görüldü. Daha sonra ise ayrı başlıklar altında tarafların bu deliller çerçevesindeki açıklamalarını kaydederek onlar hakkında değerlendirme yapacağız. Bu deliller maddeler halinde şu şekilde sıralanabilir:

I- İbn Abbas'ın naklettiği rivayete göre Rasûlullah Meymûne (öl. 51/671) ile ihramlı olduğu sırada nikâhlanmıştır. ${ }^{13}$

II- Ebû Râfi"nin nakline göre ise Rasûlullah Meymûne ile evlendiği vakit ihramlı değildir. ${ }^{14}$

III- Yezîd b. el-Esam tarikine göre bizzat Meymûne, evlendiklerinde ihramlı olmadıklarını haber vermiştir. ${ }^{15}$

IV- Hz. Osman'ın aktarımına göre Rasûl-i Ekrem, “İhramlı bir kimse kendisini veya bir başkasını nikâhlayamaz dünürcü de olamaz." ${ }^{16}$ buyurmuştur.

V- Hacla ilgili şu ayet de bu çerçevede zikredilmiştir: "Hac esnasında kadına yaklaşmak, günah sayılan davranışlara yönelmek, kavga etmek yoktur."17

Aşağıdaki açıklamalarda görüleceği üzere taraflar aklî delillere de başvurmuştur. Mezkûr deliller çerçevesinde tartışmanın nirengi noktasını rivayetlerin oluşturduğu görülmektedir. Bu sebeple meseleye doğrudan temas etmediği düşünülen ayet rivayet delillerinden sonra verilmiştir.

\section{CEVAZ VERENLERINN GÖRÜŞLERİ}

Meydânî'nin (öl. 1298/1881) kaydettiğine göre Hanefî fakihler, hac veya umre yahut bu ikisinin birlikte yapıldığı ihramlı evliliğin hükmünün

\footnotetext{
${ }^{13}$ Ebû Abdullah Muhammed el-Buhârî, Sahîhu'l-Buhârî, thk. Mustafa Dîb el-Buğâ (Beyrut: Dâru İbn Kesîr 1993), "Megâzî̀”, 41.

${ }^{14}$ Ebu'l-Hüseyin Müslim, Sahîhu Müslim. nşr. Muhammed Fuâd Abdulbâkî (Kahire: Dâru İhyâi'l-Kütübi'l-Arabiyye, 1991), "Nikâh", 46.

15 Müslim, "Nikâh", 46.

16 Süleyman b. el-Eş‘as Ebû Dâvud, Sünenü Eb̂̂ Dâvud, thk. Şu'ayb el-Arnaût vd. (Dimaşk: Dâru'l-Risâleti'l-Âlemiyye, 2009), "Menâsik", 38.

17 el-Bakara 2/197.
} 
caiz olduğu fikrindedir. ${ }^{18}$ Hanefîler görüşlerini temellendirme adına yukarıda zikredilen delillerin pek çoğunun kendi lehlerine olduğunu ifade etmişlerdir. Metin ve senet açısından sağlam olduğu anlaşılan İbn Abbas rivayetinin Hanefî fakihlerin görüşlerini temellendirmede önemli bir rol üstlendiği söylenebilir. Nitekim Hanefîlerin bu rivayeti sıklıkla aktarması da bunun göstergelerinden biridir. ${ }^{19}$

Tirmizî (öl. 279/892), İbn Abbas'tan gelen Meymûne rivayeti çerçevesinde süren tartışmada doğru olanın evliliğin ihramlı iken gerçekleştiği şeklindeki görüş olduğunu, cinsel ilişkinin ise ihramdan çıktıktan sonra vaki olduğunu ifade eder. Onun kaydına göre İbn Abbas tariki sahihtir. ${ }^{20}$ Cessâs (öl. 370/981) ise İbn Abbas rivayetinin mana cihetinden aksi yöndeki rivayetlerden evla olduğunu belirterek görüşlerini temellendirmeye çalışır. Öte yandan görüşleriyle çatışan diğer rivayetlerin istidlalini geçersiz kılmaya çabalar. ${ }^{21}$

İbn Abbas rivayetinin muteber olduğunu teyit eden Aynî (öl. 855/1451) ihramlı halde evliliğe meşruiyet kazandıran bu rivayetin Rasûlullah'a hususilik arz eden bir mesele olarak değerlendirilemeyeceğini belirtir. Zira ona göre buna işaret eden herhangi bir delil veya karine yoktur. Aynî'nin işaret ettiği mesele dikkate alındığında Hanefîlerin, rivayet etrafında oluşturulan her türlü şüpheyi çürütmeye çalıştıkları ifade edilebilir.

İhramlı kadınla evliliği haram olarak telakki eden âlimlerin hüccet kabul ettiği, "İhramlı bir kimse kendisini veya bir başkasını nikâhlayamaz dünürcü de olamaz." şeklindeki Hz. Osman rivayeti, ihramlı halde evliliğe cevaz veren Hanefî fakihlerin görüşü ve tabiatıyla istidlal ettikleri İbn Abbas tarikli Meymûne rivayeti ile teâruz etmektedir. Hanefîlerin bu teâruzu ortadan kaldırmak için bazı açıklamalar yaptıklarını görmekteyiz. Ne var ki onlar, aslında Hz. Osman rivayetinin de kendilerini desteklediğini dile getirmektedir. Buna göre onlar açısından deliller arasında herhangi bir teâruz olmadığı söylenebilir.

Bunu sarih bir şekilde ifade eden Aynî, İbn Abbas ve Hz. Osman rivayetleri arasında herhangi bir teâruz bulunmadığını belirtir. Çünkü ona

\footnotetext{
${ }^{18}$ Abdulganî b. Tâlib el-Meydânî, el-Lubâb fî̀ şerhi'l-Kitâb, nşr. Mahmud Emin en-Nevâvî (Beyrut: el-Mektebetü'1-İlmiyye, ts.), 3/7.

${ }_{19}$ Muhammed b. el-Hasan eş-Şeybânî, Kitâbu'l-Hücce 'alâ ehli'-Medîne, nşr. Seyyid Mehdî Hasan el-Kîlânî (Beyrut: Âlemü'l-Kütüb, 1983), 2/217.

${ }^{20}$ Ebû İsa Muhammed et-Tirmizî, es-Sünen, thk. Ahmed Muhammed Şâkir vd. (Misır: Şirketü Mektebeti ve Matba'ati Mustafâ el-Bâbî, 1962-1977), "Hac", 24.

${ }^{21}$ Ebû Bekir Ahmed el-Cessâs, Ahkâmu'l-Kur'ân, thk. Muhammed es-Sâdık Kamhâvî (Beyrut: Dâru İhyâi't-Türâsi'l-'Arabî-Müessesetü't-Târîhi'l-'Arabî, 1992), 5/331.
} 
göre teâruzdan söz etmek için deliller arasında sıhhat yönünden denklik bulunması gerekir. İbn Abbas rivayetini önde gelen büyük âlimler nakletmişken Hz. Osman rivayetinin ravileri arasında ilim ve hafıza cihetinden zayıf olan Nübeyh b. Vehb bulunmaktadır. Bu durumda İbn Abbas ve Hz. Osman rivayetleri arasında denklik olmadığından teâruz da söz konusu değildir. Bu sebeple İbn Abbas rivayeti tercihe şayandır. Buna göre -cumhurun iddia ettiği şekliyle- Hz. Osman rivayetinin İbn Abbas rivayetini neshettiği şeklindeki bir yorum ikna edici olmaktan uzaktır. ${ }^{22}$ Bir diğer ifadeyle ihramlı halde evlilik daha önce mubah iken Hz. Osman rivayetinin bu mubahlığ̣ yasaklama olarak değiştirdiği ileri sürülemez.

Hz. Osman rivayetini muteber gören Tahâvî (öl. 321/933) ise bu rivayetin iki şekilde tevil edilebileceğini belirtir. Onun da kaydettiği gibi birinci tevile göre insanların ihramlı oldukları halde evlenmeleri onların cinsel ilişkiye girmelerine neden olabilir ki bundan endişe eden Rasûlullah, ihramlı halde evliliği uygun görmedi. Fakat kendi nefsi için herhangi bir endişe taşımadığından kendisi ihramlı bulunduğu sırada evlilik yaptı. Bu yorumdan anlaşıldığı kadarıyla Rasûlullah aslında ihramlı halde evlenmeyi sakıncalı görmemektedir. Tahâvî'nin kaydettiği ikinci tevile göre ise aslında yasaklanan evlilik akdi inşa etmek değil, ihramlı haldeyken cinsel ilişki kurmaktır. ${ }^{23}$ Zeylaî(öl. 743/1343) cinsel ilişkinin yasaklanmas1nın evlilik akdinin oluşumunun yasaklanmasını da gerektirmez, diyerek Tahâvî'nin açıklamasının paralelinde görüş serdeder. ${ }^{24}$

Beyan edilen ikinci tevil, yani yasaklananın evlilik değil, ihramlı haldeyken cinsel ilişki kurmak şeklindeki açıklama, Hanefî fakihleri nazarında nikâh lafzının kelime anlamı olan cinsel ilişkinin şer'î metinlerde de kendisine yer bulduğu fikrine dayanır. Buna göre nikâh kelimesi bu vb. metinlerde aksini ifade eden bir karine bulunmadıkça hakiki manada yani cinsellik anlamında kullanılmaktadır. Örneğin onlar, “Ĕ̆ger (koca) kadını ( $i k i$ talâktan sonra) boşarsa, ondan sonra kadın bir başka erkekle nikâhlanmadıkça onu alması kendisine helal olmaz." ${ }^{25}$ ayeti mucibince kadının ilk kocaya helal olması için bir başka erkekle evlilik akdi yapma yanında cinsel ilişki kurmayı da şart koşmuştur. Yine onlar, "Zinadan değil nikâhtan dünyaya geldim."." riva-

${ }^{22}$ Bedreddin Muhammed b. Ahmed el-Aynî, ‘Umdetül-kârî şerhu Sahîhil-Buhârî (Beyrut: Dâru'l-Fikr, ts.), 10/197.

${ }^{23}$ Tahâvî, İhtilâfu'-'ulemâ, 2/115, 117.

${ }^{24}$ Ebû Muhammed Osman b. Ali ez-Zeylaî, Tebyînu'-hakâik şerhu Kenzi'd-dakâik (Bulak: Matba'atü'1-Kübra'1-Emîriyye, 1313-1315), 2/110.

${ }^{25}$ el-Bakara 2/230.

${ }^{26}$ Muhammed Nâsıruddîn Elbânî, İrvâu '-ğalîl fì tahrîc-i ehâdîs-i Menâri's-sebîl (Beyrut: elMektebetü'l-İslâmî, 1979), 6/329. 
yetinde de cinsel ilişkinin hakiki anlamda geldiğini vurgulamıştır. Çünkü bu rivayette kişinin dünyaya gelmesinin zina yoluyla değil de mubah olan cinsel ilişki sayesinde olduğu haber verilmiştir. ${ }^{27} \mathrm{Bu}$ çerçevede Serahsî (öl. 483/1090) "İhramlı bir kimse kendisini veya bir başkasını nikâhlayamaz dünürcü de olamaz" rivayetindeki "يُكَ" lafzından kastın akit değil cinsel ilişki olduğunu belirtmiştir. ${ }^{28}$ Fakih ve muhaddis kimliğine sahip Aynî de bu yönde açıklamalarda bulunmuştur. ${ }^{29}$

Hanefi fakihler, Hacda kadına yaklaşmayı ifade eden ayetle de istidlal etmiştir. Bu ayetteki "فلا رفث" ifadesinden kastın cinsel ilişki olduğunu, bu ifadenin "Oruç gecesinde kadınlarınıza yaklaşmak size helâl kılındı." de aynı anlamda kullanıldığını dile getirmişlerdir. Onların hacda yasaklananın sadece cinsel ilişki olduğunu işaret eden bu nassa dayanan görüşlerinin temelinde nassa yani ayetlere hadisle dahi olsa da ziyade olamayaca$\breve{g}_{1}$ fikri yatmaktadır. Buna göre evlilik akdi caiz olmalıdır. ${ }^{31}$

Hanefî fakihler görüşlerini temellendirme adına kıyas deliline de başvurmuştur. Onlar nazarında ihramlı olan bir şahsın evlilik akdi inşa etmesi yine ihramlı olan kişinin cariye veya güzel koku yahut da gömlek satın almasına, yani alış-veriş akdine mukayese edilir. Cariyeye yaklaşma, güzel koku sürünme ve gömlek giymenin ihramlı olan kimseye haram olması bunları satın almayı nehyetmediği gibi cinsel ilişkinin haram olması da evlilik akdi yapmaya mani değildir. ${ }^{32}$

Görüldügü kadarıyla Hanefî fakihlerin en güçlü delili Rasûllulah'ın Meymûne ile ihramlı halde evlendiğini haber veren İbn Abbas rivayetidir. Nitekim aşağıda da geleceği gibi evliliğe cevaz veremeyen âlimlerin bir kısmı bu delilin sıhhatini kabul etmektedir. Bundan ötürü onların temel delili ve açıklamalarına ihramlı evliliğe cevaz veremeyen âlimlerin yoğun bir tenkitte bulunması daha anlaşır olmaktadır.

Bununla birlikte Hz. Osman rivayeti Hanefîlerin görüşleriyle çatışmaktadır. Bu noktada onlara göre asıl yasaklanan evlilik değil, ihramlı haldeyken cinsel ilişki kurmak şeklindeki açıklama tek başına yeterli değildir.

\footnotetext{
${ }^{27}$ Ebu'l-Fazl Abdullah b. Mahmûd el-Mevsılî, el-İhtiyâr li-ta'lîli'l-Muhtâr, nşr. Mahmûd Ebû Dakîka (Beyrut: Dâru'l-Kütübi'l-İlmiyye, ts.), 3/81.

${ }^{28}$ Ebû Bekir Muhammed b. Ebû Sehl es-Serahsî, Ahmed, el-Mebsût (Beyrut: Dâru'l-Ma'rife, 1989), 4/191.

29 Aynî, 'Umdetül-kârî, 20/111.

${ }^{30}$ el-Bakara 2/187.

31 Ebû Cafer Ahmed b. Muhammed et-Tahâvî, Ahkâmu'l-Kur'ani'l-Kerîm, thk. Saadettin Önal (İstanbul: İSAM, 1998), 2/31-32.

${ }^{32}$ Tahâvî, Şerhu me'âni'-âsâr, 2/270.
} 
Fakat Hanefî fakihleri nazarında nikâh lafzının şer'î metinlerde cinsel ilişki anlamında kullanıldığı fikri ise sadra şifa olacak düzeydedir. Diğer yandan Aynî nikâh lafzı çerçevesindeki eleştirilerden olsa gerek, Hz. Osman rivayetinin aslında delil olamayacağını söyler. Bu durumda kendilerinin görüşüyle çelişen bir delilden söz etmek mümkün değildir. Ona göre İbn Abbas rivayeti kâfi bir delildir. Bu da bu delilin niçin tartışmanın nirengi noktasını teşkil ettiğini açığa vurmaktadır.

Yine onların, Hac sırasında kadına yaklaşmayı yasaklayan ayet bağlamındaki açıklamaları da ikna edici görünmektedir. Kıyas delillerinin de en az rivayetler kadar ikna edici ve sağlam olduğu söylenebilir. Aşağıda da geleceği üzere ihramlı halde evliliğe cevaz vermeyen âlimlerin kıyas delilini fâsid olarak nitelemeleri ise çok da haklı gerekçelere dayanmaz.

\section{YASAKLAYANLARIN GÖRÜŞLERİ}

İhramlı kadınla evliliğe cevaz vermeyen âlimler yukarıda zikredilen İbn Abbas rivayeti hariç diğer bütün delillerin kendi görüşlerini desteklediğini belirtmişlerdir. Çeşitli açıklamalar ve gerekçelerle görüşlerini temellendirmeye çalışmışlardır. Yalnız onlar İbn Abbas rivayetini de dikkate almıştır. Bu bağlamda Rasûlullah ile Meymûne evlendiği sırada onların ihramlı olmadıkları şeklinde nakilde bulunan Ebû Râfi'(öl. 40/660) ve Yezîd b. el-Esam tarikinin aksini ifade eden İbn Abbas rivayeti çerçevesindeki teâruzu giderme adına muhtelif açıklamalar yapmışlardır.

İbn Rüşd (öl. 595/1198) bu durumda iki yol izlenebileceğini kaydetmiştir. Birincisine göre teâruz eden delillerden birini tercih etmek gerekir. İkincisine göre ise bunların arasını cem etmek mümkündür. ${ }^{33}$ İbn Abdülberr'in (öl. 463/1071) ifadesine göre, Meymûne ile ilgili rivayeti aktaran ravilerin tamamı nikâh kıyıldığı sırada Rasûlullah'ın ihramdan çıkmış olduğunu haber verirken İbn Abbas ise bunun aksini iddia etmiştir. ${ }^{34}$ Kâdî İyâz da onu destekler mahiyette açıklamalar yapmıştır. ${ }^{35}$

İbn Abbas'a itiraz ettiği anlaşılan Saîd b. el-Müseyyeb, onun yanıld1ğını (vehmettiğini) söylemiştir. ${ }^{36}$ İbn Hazm da bunu ifade ederek Yezîd b. el-Esam tarikinden gelen haberin hakikat olduğunu dile getirmiştir. Ona

\footnotetext{
${ }^{33}$ Ebu'l-Velîd Muhammed b. Ahmed İbn Rüşd, Bidâyetül-müctehid ve nihâyetül-muktesid (Beyrut: Dâru'l-Ma'rife, 1982), 2/46.

${ }^{34}$ Ebû Ömer Yusuf b. Abdullah İbn Abdülber, et-Temhîd li-mâ fil-Muvatta mine'l-me'ânî ve'esânîd (Mağrib: Vezâretü Umûmi'l-Evkâf ve'ş-Şuûni'l-İslâmiyye, 1967), 3/153.

35 Kâdî İyâz, İkmâlu'l-Mu'lim, 4/552.

${ }^{36}$ Ebû Dâvud, "Menâsik", 39.
} 
göre bu tarikin hakikat İbn Abbas'ın tarikinin yanılgı olduğu şu üç gerekçe ile izah edilebilir:

I- Yezîd b. el-Esam rivayetinde geçtiği gibi bizzat Meymûne ihramlı olmadığını haber vermiştir ki onun kendisi hakkındaki ifadesi İbn Abbas'ın ifadesinden daha sağlamdır. Hem İbn Abbas bu konudaki nakliyle tek (ferd) kalmıştır.

II- İbn Abbas bu hadiseyi aktardığında ancak on yaşlarında bir çocuktu.

III- Rasûlullah Kaza Umresinde evlenmiştir. Daru'l-harp olan Mekke'de ateşkes gereği umre için üç gün kaldığg bu vakitte de umre menâsiki ile meşgul olduğu dikkate alındığında evliliğin ancak ihramdan çıktıktan sonra cari olduğu gibi bir sonuca varılır. ${ }^{37}$

Medine âlimlerinin cumhurunun Rasûlullah'ın Meymûne ile evlendiği sırada ihramlı olmadığı görüşünü benimsediğini nakleden İbn Abdülber de meseleyi etraflıca ele almıştır. ${ }^{38}$ Ona göre İbn Abbas rivayeti sahihtir, dolayısıyla İbn Abbas'ın vehmettiği yönündeki bilgi muteber değildir. $\mathrm{Bu}$ durumda $\mathrm{O}$, İbn Abbas tarikiyle gelen rivayetle diğer rivayetler arasinda herhangi bir tercihte bulunmaz. Bir diğer ifadeyle deliller arasında denklik olduğunu ihsas ettirerek her iki tarafın Meymûne bağlamındaki delillerinin sakıt olduğunu söyler ki bu durumda başka bir delil bulmak gereklidir. Ona göre tam da bu noktada Hz. Osman rivayeti hüccet kabul edilmelidir ki mesele vuzuha kavuşsun. ${ }^{39}$

Ebu'l-Ferec İ̉n Kudâme (öl. 682/1283) de Hz. Osman rivayetinin hücciyetine dikkat çeker. Fakat Meymûne çerçevesindeki rivayetlerin hepsinin sakıt olduğu fikrine sıcak bakmaz. Çünkü onun nazarında Ebû Râfi' tariki İbn Abbas tarikinden evladır. Dolayısıyla Ebû Râfi"'nin haberiyle istidlal etmek yerinde olacaktır. ${ }^{40}$

İbn Kayyim el-Cevziyye'nin (öl. 751/1350) de ifadelerinden anlaşıldığ 1 kadarıyla Meymûne hususundaki delillerinin sakıt olduğu şeklindeki İbn Abdülberr'in görüşü isabetli değildir. Zira İbn Kayyim el-Cevziyye evliliğin ihramlı iken gerçekleşmediğini haber veren rivayetlerin tercihe şayan olduğunu belirtir. Bu itibarla onun nazarında sakıt olan sadece İbn Abbas rivayetidir. $\mathrm{O}$, bu teâruzu giderme ve ihramlı halde evliliğin cari olmadığ1nı ispatlamak için çeşitli gerekçeler sıralamıştır. Bunlar maddeler halinde şöyledir:

\footnotetext{
37 İbn Hazm, el-Muhallâ, 5/215.

${ }^{38}$ Ebû Ömer Yusuf b. Abdullah İbn Abdülber, el-isstizkâr (Beyrut: Dâru'l-Kütübi'l-İlmiyye, 2002), 4/117.

${ }^{39}$ İbn Abdülber, et-Temhîd, 3/153.

${ }^{40}$ İbn Kudâme, eş-Şerhu'-kebîr, 3/312.
} 
I- Ebû Râfi', Rasûlullah evlendiği vakit âkil-bâliğ iken İbn Abbas ise daha ergenliğe ermemiştir.

II- Ebû Râfi' bu umrede bizzat bulunurken İbn Abbas bulunmamıştır.

III- Rasûl-i Ekrem'in ihramlı bir şekilde Mekke'ye girdiği ve tavafın akabinde ihramdan çıkmış olduğu öncülü nazarı dikkate alınırsa Mekke'ye girmeden evlenmediği gibi girdikten sonra da umre menâsiki ile meşgul olduğundan ihramlı iken evlenmediği sonucuna varılabilir. Buradan anlaşıldığg gibi Rasûlullah ve Meymûne'nin ihramdan çıktıktan sonra evlendiği sonucuna varılır. İbn Kayyim bu üç gerekçe nedeniyle Ebû Râfi‘ rivayetini İbn Abbas rivayetine tercih etmiştir. ${ }^{41}$

Muhaddis Kurtubî (öl. 656/1258) de çeşitli gerekçeler sunarak İbn Abbas rivayeti bağlamında problemi gidermeye çalışır. Bu gerekçelerden birine göre İbn Abbas rivayetindeki "محرم" lafzı ihramlı kişiye değil de harem bölgesinde bulunan kimseye hamledilebilir. Bu durumda Rasûlullah'ın söz konusu evliliği, ihramdan çıktıktan sonra harem bölgesindeyken vaki olmuş olmalıdır. Bir diğer tevile göre ise ihramlı evlilik gibi nikâh konularındaki kimi meseleler Rasûlullah'a mahsus bir mana taşır. ${ }^{42} \mathrm{Bu}$ vb. gerekçeleri sıralayan Nevevî (öl. 676/1277) de Şâfîi fakihleri nezdinde ihramlı evlilik hususunun Rasûlullah'a mahsus olmasının esah bir görüş olduğunu ifade eder. Öte yandan aksi bir görüş olduğunu da belirtir. ${ }^{43}$ Kirmânî (öl. 786/1384) de delillerin teâruz ettiği savından hareketle hususilik görüşünün tercihe layık olduğunu teyit eder. ${ }^{44}$ Hususilik fikrine temas eden İbn Hacer el-Askalânî (öl. 852/1449) ise yasaklamanın Rasûlullah'ı da kapsamasının evla olduğunu dile getirerek hususilik fikrine pek sıcak bakmaz. ${ }^{45}$

İhramlı bulunmanın evlilik engeli oluşturduğunu ifade eden âlimler Hz. Osman tarikiyle varit olan hadisi de temel almıştır. İbn Abdülber bu rivayetin Raşit halifelerin ameline muvafık olduğunu serdetmiştir. ${ }^{46}$ İbn Battal (öl. 449/1057) bu rivayetin ihramlı evliliği fâsid yaptığını ve akdin feshi gerektiğini söylemiştir. ${ }^{47}$ Mâverdî (öl. 450/1058) ihramlı halde inşa edilen evlilik

${ }^{41}$ Muhammed b. Ebû Bekir İbn Kayyim el-Cevziyye, Zâdu 7-me'âd fî hedyi hayri'l-íbâd, thk. Şuayb el-Arnaût-Abdulkâdir el-Arnavut (Beyrut ve Kuveyt: Müessesetü'r-Risâle ve Mektebetü'1-Menâri'-İslâmiyye, 1994), 5/102-104.

${ }^{42}$ Ebu'l-Abbas Ahmed b. Ömer el-Kurtubî, el-Müfhim li-mâ eşkele min Telhîsi kitâbi Müslim, thk. Muhyiddin Dîb Müstû vd. (Dımaşk ve Beyrut: Dâru İbn Kesîr ve Dâru'l-Kelimi'tTayyib, 1996), 4/105-106.

${ }^{43}$ Ebû Zekeriyyâ Yahyâ en-Nevevî, Sahîhu Müslim bi-şerhi'n-Nevevî (Mısır: el-Matba'atü'lMisriyye, 1929-1930), 9/20.

${ }^{44}$ Muhammed b. Yusuf b. Ali el-Kirmânî, el-Buhârî bi-şerhi'l-Kirmânî (Beyrut: Dâru İhyâi'tTürâsi'l-Arabî, 1981), 19/88.

45 İbn Hacer, Fethu' '-bârî, 4/52.

${ }^{46}$ İbn Abdülber, et-Temhîd, 3/153.

${ }^{47}$ Ebu'l-Hasan Ali b. Halef İbn Battâl, Şerhu Sahîhil-Buhârî, nşr. Ebû Temîm Yâsir b. İbrâhim (Riyad: Mektebetü'r-Rüşd, 2003), 4/509. 
akdinin Şâfiî fakihler nezdinde bâtıl olduğunu kaydetmiştir. ${ }^{48}$ İbn Abdülber de genel bir ifade kullanarak âlimlerin buna rağmen kıyılan nikâhın bâtıl olacağı görüşünde olduklarını nakletmiştir. ${ }^{49}$ Tahâvî'nin kaydettiğine göre ihramlı kadınla evliliğe cevaz vermeyen fakihlerden olan Leys b. Sa'd ve İmam Mâlik nezdinde bu şekilde evlenen taraflar tefrik edilerek bu, bir boşama sayılmıştır. ${ }^{50}$ Buradan anlaşıldığı kadarıyla onlar bu nikâhı bâtıl olarak nitelememiştir.

İbn Hazm, Hz. Osman rivayetinin hüccet olduğunu vurgulayarak teâruz sorununun çözüme kavuştuğunu söyler. Yukarıda da geçtiği üzere onun nazarında İbn Abbas rivayeti sahih değildir. Bununla beraber İbn Abbas rivayeti'nin sahih olup Meymûne rivayetinin sahih olmadığı ileri sürülse bile yine de kendi görüşlerinin doğru olacağını vurgular. Bu durumda İbn Abbas rivayeti aslında mubah olan ihramlı evliliği haber vermekten öte bir anlam taşımaz. Çünkü zaten Yüce Allah nikâh kıymayı daha önce oruçluya, ihramlı olana, mücahit ve itikafta olana mubah k1lmıştır. Meymûne rivayeti sahih kabul edilmediği bu durumda İbn Abbas rivayeti zâid bir anlam taşır. Ancak Rasûlullah'ın, "İhramlı bir kimse kendisini veya bir başkasını nikâhlayamaz dünürcü de olamaz" buyruğu mubah olan ihramlı evliliği dolayısıyla sahih olarak nitelenen İbn Abbas'ın sözünü neshetmiş olur. Böylece yakîn olan nesih bilgisi dururken zan ifade eden İbn Abbas tarikinin istidlal edilmesi uygun değildir. İhramlı evliliğe cevaz vermeyen âlimlerin zikri geçen deliller çerçevesinde Hanefî fakihlerin bazı gerekçe ve açıklamalarına itiraz ettikleri görülmektedir. Bu manada İbn Hazm ihramlının evlilik akdinin caiz olduğu fikrinin cariye satın almanın mubahlığına kıyaslanmasına karşı çıkar. Zira ona göre hakikatle çatışan bir kıyas sahih olmaz. Binâenaleyh bu kıyas bâtıldır. ${ }^{51}$ Yine İbn Hacer de bu kıyaslamanın geçersiz olduğunu belirterek bu kıyasın geçersizliğini $\mathrm{Hz}$. Osman rivayetine yani sünnet muhalefet gerekçesine dayandırır. ${ }^{52}$

Ebu'1-Ferec İbn Kudâme ise böyle bir kıyaslamayı evlilik akdinin cariye alma akdinden farklılık arz ettiği savına hamleder. Onun da vurguladığı gibi evlilik genellikle cinselliği beraberinde getirir, oysaki cariye satın alma hizmet ve ticaret gibi muhtelif sebepleri de ihtiva eder. ${ }^{53}$ Anlaşıldığ1 kadarıyla bu âlimlerin, ihramlı halde evliliğin yasaklanması gerektiği kanaati cinsel ilişkinin muhrim için haram olduğu görüşüne dayanır. Nite-

\footnotetext{
${ }^{48}$ Ali b. Muhammed b. Habîb el-Mâverdî, el-Hâvi'l-kebîr (Beyrut: Dâru'l-Kütübi'l-İlmiyye, 1994), 4/123.

49 İbn Abdülber, el-ístizkâr, 4/118.

50 Tahâvî, İhtilâfu' l-'ulemâ, 2/114.

51 İbn Hazm, el-Muhallâ, 5/216.

${ }^{5}$ İbn Hacer, Fethu'l-bârî, 4/52.

53 İbn Kudâme, eş-Şerhu'l-keb̂̂r, 3/312.
} 
kim İbn Kayyim el-Cevziyye bu yasaklanmanın cinsel ilişkiye mani olmanin sedd-i zerâi ilkesi mucibince olduğunu ifade eder. ${ }^{54}$

Nikâh lafzının "İhramlı bir kimse kendisiniveyabir başkasını nikâhlayamaz..." hadisinde cinsel ilişki anlamında kullanıldığı şeklindeki Hanefî fakihlerin açıklamalarını yerinde bulmayan İbn Hacer, rivayetin devamındaki " و'

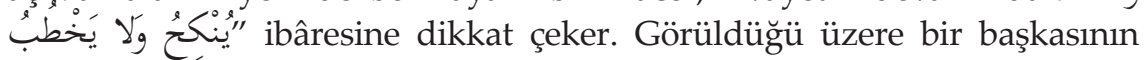
nikâhlanmasi ve dünürcü olmak da yasaklanmaktadır. Buna göre nikâh kelimeş̧nin cinsel ilişki anlamında kullanıldığı iddiası rivayetin baş kısmı olan " لا يَنْكح المُحْرُمُ" için isabetli kabul edilse dahi devamı için muteber değildir.

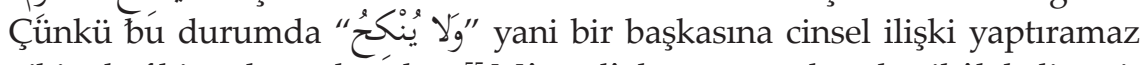
gibi tuhaf bir anlam çıkacaktır. ${ }^{55}$ Mâverdî de aynı gerekçeyle nikâh kelimesinin cinsel ilişki anlamına hamledilmesini doğru bulmaz. ${ }^{56}$

Bu âlimlerin itirazlarının temelinde şer î örfte nikâh kelimesinin akit anlamında bulunduğu görüşü yatmaktadır. ${ }^{57}$ Nitekim buna dikkat çeken Nevevî bir lafızda lugavî ve şer'î anlam müşterek olarak bulunduğunda şerî̂ anlamın takdim edileceğini belirtir. Bu sebeple "لا يَنْكح الُْحْرَ hadisinde cinsel ilişkinin değil, akit anlamının isabetli olduğunu béyan eder. ${ }^{58}$

Ebû Râfi' ve İbn Abbas rivayetleri çerçevesinde yapılan açıklamaların teâruzu ortadan kaldırmak bir yana daha da artırdığı görülmektedir. Ebû Râfi"nin tarikinin İbn Abbas tarikinden evla olduğu şeklindeki görüş ve buna dair zikredilen gerekçeler ise sadra şifa olacak düzeyde değildir. Çünkü İbn Abbas'ın yaşının küçüklüğü veya söz konusu umrede hazır bulunmaması, rivayetine herhangi bir halel getirmez. Şöyle ki zaten onun rivayetlerinin pek çoğu doğrudan Rasûlullah'tan değil sahabeden nakil niteliği taşımaktadır. Sahabe mürseli olan pek çok rivayeti gibi bu rivayeti de muteber ve tercihe şayan olup amel edilebilir bir durumdadır. Bu itibarla Ebû Râfi"nin rivayetinin İbn Abbas'a tercih edilmesinin isabetli olmadığı kanaatindeyiz.

Aslına bakılırsa Ebû Râfi' ve İbn Abbas'a ait bu iki zıt rivayetin bir diğerine tercih edilmesi gerekmez. Çünkü her ikisinin de muteber olması muhtemeldir. Yukarıda da vurgulandığı gibi ihramlı kadınla evliliğe cevaz veren âlimler aslında muhrimin cinsel ilişki kurmasına karşı çıkar. Açıkça anlaşıldığı kadarıyla gerçekte yasaklanan evlilik değil, ihramlı olunduğu sırada cinsel ilişki kurulmasıdır. Kanaatimizce bu değerlendirme teâruzu ortadan kaldırmaktadır.

${ }^{54}$ Muhammed b. Ebû Bekir İbn Kayyim el-Cevziyye, I'lâmu'l-muvakkı'în 'an Rabbil-'âlemîn, nşr. Muhammed Abdusselam İbrâhim (Beyrut: Dâru'1-Kütübi'l-İlmiyye, 1996), 3/113.

${ }_{55}$ İbn Hacer, Fethu' -bârî, 4/52.

${ }^{56}$ Mâverdî, el-Hâvî̀, 4/124.

${ }^{57}$ Mâverdî, el-Hâvî, 9/216.

${ }^{58}$ Ebû Zekeriyyâ Yahyâ en-Nevevî, el-Mecmû' şerhu'l-Mühezzeb (Mısır: İdâretü't-Tibâ'ati'lMünîriyye, ts.), 7/288. 
İbn Abbas tarikini sahih addetmelerine rağmen ihramlı halde evliliğin Rasûlullah'a hususilik arz eden bir mesele olduğu yönündeki iddia ispattan yoksundur. Zira meselenin bu kapsamda değerlendirilebileceğine dair bir gerekçe zikredilmemektedir. Nitekim İbn Hacer'in hususilik ihtimaline mesafeli yaklaştığı yukarıda geçmişti. Burada olsa olsa kendi görüşleriyle bu rivayetin çatışması ihtimalinden söz edilebilir.

Cumhurun, Hanefîlere ait olan evlilik akdinin cariye satın almanın mubahlığına kıyaslanmasına ilişkin getirdikleri eleştirilerin çok da yerinde olmadığı görülmektedir. Şöyle ki bu fakihler evliliğin umumiyetle cinselliği beraberinde getirdiği, cariye satın almanın ise hizmet ve ticaret amacına matuf olduğu savından hareketle bu kıyası bâtıl addetmişlerdir. Aslına bakılırsa cariye satın almak hizmet ve ticaret gibi cinselliği de akla getirmektedir. Cinsel ilişki kurulma ihtimaline karşılık evlilik akdi yasaklandığına göre aynı ihtimali barındıran cariye satın alma da yasaklanmalıdır.

\section{SONUÇ}

İhramlı halde evlilik akdi yapmanın İslam fıkhına göre değerlendirildiği bu çalışmada İbn Abbas'ın Rasûlullah'ın Meymûne ile ihramlı olduğu sırada evlendiğini haber verdiği rivayetle aksini haber veren Ebû Râfi' rivayeti tartışma konusu olmuştur. Zikri geçen tartışmalar dikkate alındığında Hanefî fakihleri dişındaki mezhep fakihlerinin İbn Abbas rivayetini itibarsızlaştırmaya dönük ifadelerinin çok da isabetli olmadığ 1 düşünülmektedir. Hanefî fakihlerin en sağlam delili olan İbn Abbas rivayetinin sahih olduğunu, aksi görüşteki âlimlerin bir kısmının da kabul etmesi bu rivayetin muteber olduğunun kanitıdır.

Bununla birlikte, ihramlının nikâhlanamayacağını ifade eden Hz. Osman rivayetini Hanefîlerin dikkate alması fakat burada yasaklananın akit yapmak değil de cinsel ilişki kurmak şeklindeki görüşleri sünnet deliline ne denli önem verdiklerinin bir göstergesidir. Neticede tarafların zikrettiği deliller ve değerlendirmeler dikkate alındığında deliller arasında herhangi bir teâruz olmadığı anlaşılmaktadır. Bu itibarla ihramlı kadınla evlenme hususunda Ebû Râfi' tarikinin İbn Abbas tarikine tercih edilmesi isabetli görülmemektedir. Çünkü İbn Abbas'ın yaşının küçüklüğü veya söz konusu umrede hazır bulunmaması gibi sebepler bu rivayete herhangi bir halel getirmez. İbn Abbas'ın rivayetlerinin pek çoğunun sahabe mürseli olduğu nazarı dikkate alındığında bu iddiaların yersiz olduğu görülmektedir. Zira diğer pek çok rivayeti gibi bu rivayeti de muteber ve amel edilebilirdir. Ezcümle açıkça anlaşıldığı kadarıyla gerçekte muhrime yasak olan şeyin evlilik akdi değil, cinsel ilişki kurmak olduğu anlaşlır. Çünkü kişinin hac ve umre menâsikiyle meşgul olduğu bir sırada ona halel getirecek bir davranıştan uzak durması gerekmektedir. 


\section{KAYNAKÇA}

Aynî, Bedreddin Muhammed b. Ahmed. 'Umdetül-kârî şerhu Sahîhi'Buhârî. 25 Cilt. Beyrut: Dâru'l-Fikr, ts.

Bilmen, Ömer Nasuhi. Hukukı İslâmiyye ve Istılahatı Fıkhiyye Kamusu. 8 Cilt. İstanbul: Bilmen Yayınevi, 1976.

Buhârî, Ebû Abdullah Muhammed. Sahîhu'l-Buhârî. thk. Mustafa Dîb elBuğâ. 6 Cilt. Beyrut: Dâru İbn Kesîr 1993.

Cessâs, Ebû Bekir Ahmed b. Ali er-Râzî. Ahkâmu'-Kur'ân. thk. Muhammed es-Sâdık Kamhâvî. 5 Cilt. Beyrut: Dâru İhyâi't-Türâsi'l-‘ArabîMüessesetü't-Târîhi'l-'Arabî, 1992.

Dağcı, Şamil. “İslâm Aile Hukukunda Evlenme Engelleri II (Geçici Evlenme Engelleri)”. Ankara Üniversitesi İlahiyat Fakültesi Dergisi. 41/1 (2000), 137-194.

Ebû Dâvud, Süleyman b. el-Eş'as. Sünenü Eb̂̂ Dâvud. thk. Şu'ayb el-Arnaût vd. 7 Cilt. Dımaşk: Dâru'1-Risâleti'1-Âlemiyye, 2009.

Elbânî, Muhammed Nâsiruddîn. İrvâu'l-ğalîl fî̀ tahrîc-i ehâdîs-i Menâri'ssebîl. 9 Cilt. Beyrut: el-Mektebetü'1-İslâmî, 1979.

Hallâf, Abdulvehhâb. Ahkâmu'l-ahvâli'ş-şahsiyye fìş-şerî'atil-İslâmiyye. Kuveyt: Dâru'l-Kalem, 1990.

İbn Abdülber, Ebû Ömer Yusuf b. Abdullah. el-İstizkâr. 9 Cilt. Beyrut: Dâru'1-Kütübi'l-İlmiyye, 2. Basım, 2002.

İbn Abdülber, Ebû Ömer Yusuf b. Abdullah. et-Temhîd li-mâ fil-Muvatta mine'l-me ânî ve'l-esânîd. 26 Cilt. Mağrib: Vezâretü Umûmi'l-Evkâf ve'ş-Şuûni'l-İslâmiyye, 1967.

İbn Battâl, Ebu'1-Hasan Ali b. Halef. Şerhu Sahîhi'-Buhârî. nşr. Ebû Temîm Yâsir b. İbrâhim. 10 Cilt. Riyad: Mektebetü'r-Rüşd, 2003.

İbn Hacer, Ebu'l-Fazl Ahmed el-Askalânî. Fethu'l-bârî bi-şerhi Sahîhi'l-Buhârî. 13 Cilt. Beyrut: Dâru'l-Ma'rife, 1960.

İbn Hazm, Ebû Muhammed Ali. el-Muhallâ bi'l-âsâr. 12 Cilt. Beyrut: Dâru'lKütübi'l-İlmiyye, 2003.

İbn Kayyim el-Cevziyye, Muhammed b. Ebû Bekir. I'lâmu'l-muvakkı'în 'an Rabbi'-'âlemîn. nşr. Muhammed Abdusselam İbrâhim. 4 Cilt. Beyrut: Dâru'l-Kütübi'l-İlmiyye, 1996.

İbn Kayyim el-Cevziyye, Muhammed b. Ebû Bekir. Zâdu'l-me'âd fî hedyi hayri'-'ibâd. thk. Şuayb el-Arnaût-Abdulkâdir el-Arnavut. 5 Cilt. 
Beyrut ve Kuveyt: Müessesetü'r-Risâle ve Mektebetü'1-Menâri'1İslâmiyye, 27. Basım, 1994.

İbn Kudâme, Ebu'l-Ferec. eş-Şerhu'-kebîr 'alâ metni'l-Mukni'. 13 Cilt. Beyrut: Dâru'l-Kitâbi'l-Arabî, 1983.

İbn Rüşd, Ebu'l-Velîd Muhammed b. Ahmed. Bidâyetül-müctehid ve nihâyetül-muktesid. 2 Cilt. Beyrut: Dâru'l-Ma'rife, 6. Basım, 1982.

Kâdî İyâz, Ebu'l-Fazl. İkmâlu'-Mu'lim bi-fevâidi Müslim. 9 Cilt. Mansûre: Dâru'l-Vefâ, 1998.

Kirmânî, Muhammed b. Yusuf b. Ali. el-Buhârî bi-şerhi'l-Kirmânî. 25 Cilt. Beyrut: Dâru İhyâi't-Türâsi'l-Arabî, 2. Basım, 1981.

Kurtubî, Ebu'l-Abbas Ahmed b. Ömer. el-Müfhim li-mâ eşkele min Telhîsi kitâbi Müslim. thk. Muhyiddin Dîb Müstû vd. 7 Cilt. Dımaşk ve Beyrut: Dâru İbn Kesîr ve Dâru'1-Kelimi't-Tayyib, 1996.

Mâverdî, Ali b. Muhammed b. Habîb. el-Hâvi'l-kebîr. thk. Ali Muhammed Mu'avvid ve Âdil Ahmed Abdulmevcûd. 18 Cilt. Beyrut: Dâru'lKütübi'l-İlmiyye, 1994.

Mevsilî, Ebu'l-Fazl Abdullah b. Mahmûd. el-İhtiyâr li-ta 'lîli'l-Muhtâr. nşr. Mahmûd Ebû Dakîka. 5 Cilt. Beyrut: Dâru'l-Kütübi'l-İlmiyye, ts.

Meydânî, Abdulganî b. Tâlib. el-Lubâb fì şerhil-Kitâb. nşr. Mahmud Emin en-Nevâvî. 4 Cilt. Beyrut: el-Mektebetü'l-İlmiyye, ts.

Müslim, Ebu'l-Hüseyin. Sahîhu Müslim. nşr. Muhammed Fuâd Abdulbâkî. 4 Cilt. Kahire: Dâru İhyâi'l-Kütübi'l-Arabiyye, 1991.

Nevevî, Ebû Zekeriyyâ Yahyâ b. Şeref. el-Mecmû' şerhu'-Mühezzeb. 20 Cilt. Mısır: İdâretü't-Tıbâ'ati'l-Münîriyye, ts.

Nevevî, Ebû Zekeriyyâ Yahyâ. Sahîhu Müslim bi-şerhi'n-Nevevî. 18 Cilt. M1sir: el-Matba'atü'l-Misriyye, 1929-1930.

Serahsî, Ebû Bekir Muhammed b. Ebû Sehl Ahmed. el-Mebsût. 30 Cilt. Beyrut: Dâru'l-Ma'rife, 1989.

Şeybânî, Muhammed b. el-Hasan. Kitâbu'-Hücce 'alâ ehlil-Medîne. nşr. Seyyid Mehdî Hasan el-Kîlânî. 4 Cilt. Beyrut: Âlemü'l-Kütüb, 1983.

Tahâvî, Ebû Cafer Ahmed b. Muhammed. Ahkâmu'-Kur'ani'l-Kerîm. thk. Saadettin Önal. 2 Cilt. İstanbul: İSAM, 1998.

Tahâvî, Ebû Cafer Ahmed b. Muhammed. Muhtasaru İhtilâfi'-‘ulemâ. thk. Abdullah Nezîr Ahmed. Beyrut: Dâru'l-Beşâiri'l-İslâmiyye, 1995.

Tahâvî, Ebû Cafer Ahmed b. Muhammed. Şerhu me'ânil-âsâr. thk. Muham- 
med Zührî en-Neccâr ve Muhammed Seyyid Câdelhak. 5 Cilt. Beyrut: Âlemü'l-Kütüb, 1994.

Tirmizî, Ebû İsa Muhammed es-Sünen. thk. Ahmed Muhammed Şâkir vd. 5 Cilt. Mısır: Şirketü Mektebeti ve Matba'ati Mustafâ el-Bâbî, 19621977.

Zeydan, Abdulkerim. el-Mufassal fì ahkâmi't-mer'e ve'l-beyti't-müslim fi'şşerî‘atil-İslâmiyye. 11 Cilt. Beyrut: Müessesetü'r-Risâle, 1993.

Zeylaî, Ebû Muhammed Osman b. Ali. Tebyînu'-hakâik şerhu Kenzi'd-dakâik. 6 Cilt. Bulak: Matba'atü'1-Kübra'1-Emîriyye, 1313-1315.

Zuhaylî, Vehbe. el-Fikhu'l-İslâmî ve edilletuh. 8 Cilt. Dımaşk: Dâru'l-Fikr, 2. Basım, 1985. 